\title{
Overexpression of adrenomedullin gene markedly inhibits proliferation of PC3 prostate cancer cells in vitro and in vivo
}

\author{
Ibane Abasolo ${ }^{\mathrm{a}, \mathrm{d}, 1}$, Luping Yang ${ }^{\mathrm{a}, 1}$, Riffat Haleem ${ }^{\mathrm{a}}$, Wuhan Xiao ${ }^{\mathrm{a}}$, Ruben Pio $^{\mathrm{e}}$, \\ Frank Cuttitta ${ }^{\mathrm{e}}$, Luis M. Montuenga ${ }^{\mathrm{d}}$, James M. Kozlowski ${ }^{\text {a,c }}$, Alfonso Calvo ${ }^{\mathrm{d}}$, \\ Zhou Wang ${ }^{\mathrm{a}, \mathrm{b}, \mathrm{c}, *}$ \\ ${ }^{a}$ Department of Urology, Northwestern University Medical School, Tarry 11-715, 303 E. Chicago Ave., Chicago, IL 60611, USA \\ ${ }^{\mathrm{b}}$ Department of Molecular Pharmacology and Biological Chemistry, Northwestern University Medical School, Tarry 11-715, 303 E. Chicago Ave., \\ Chicago, IL 60611, USA \\ ${ }^{\mathrm{c}}$ The Robert H. Lurie Comprehensive Cancer Center, Northwestern University Medical School, Tarry 11-715, 303 E. Chicago Ave., Chicago, IL 60611, \\ USA \\ ${ }^{\mathrm{d}}$ Department of Histology and Pathology, University of Navarra, 31008 Pamplona, Spain

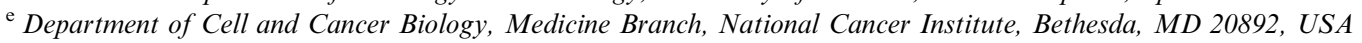

Received 17 May 2002; accepted 26 July 2002

\begin{abstract}
The expression of the gene encoding adrenomedullin (AM), a multifunctional peptide hormone, in the prostate is localized to the epithelial cells. Prostate cancer cells are derived from prostatic epithelial cells. To elucidate the potential role of the AM gene in prostate cancer progression, we have stably-transfected the PC3 human prostate cancer cell line with an AM gene expression vector. The AM-transfected PC3 sublines were studied along with parental and empty vector transfected PC 3 cells as controls. The average level of AM in the conditioned media of AM-transfected cells was $0.959 \pm 0.113 \mathrm{nM}$, a physiologically relevant concentration. The ectopic expression of AM gene inhibited the proliferation of PC3 cells in culture dishes. In addition, anchorage-independent growth of the transfected sublines was virtually abolished in soft agar assays. Flow cytometry studies showed that overexpression of AM gene caused a very significant $\mathrm{G}_{1} / \mathrm{G}_{0}$ cell cycle arrest. In vivo experiments demonstrated that $\mathrm{AM}$ gene expression markedly inhibited the growth of xenograft tumors in nude mice. Our in vivo and in vitro studies suggest that AM could strongly suppress the malignancy of prostate cancer cells, via autocrine and/or paracrine mechanisms.
\end{abstract}

(C) 2002 Published by Elsevier Science Ireland Ltd.

Keywords: Adrenomedullin; Prostate cancer; Growth inhibition; Xenograft; PC3

\section{Introduction}

Adrenomedullin (AM) is a pluripotent peptide originally isolated from human pheochromocytoma. The gene for AM is located in a single locus of chromosome 11

Abbreviations: AM, adrenomedullin; rAM, rat adrenomedullin; PAMP, proadrenomedullin N-terminal 20 peptide; RIA, radioimmunoassay; MAPK, mitogen-activated protein kinase; CRLR, calcitonin receptor-like receptor; RAMP, receptor activity modifying protein.

* Corresponding author. Tel.: +1-312-908-2264; fax: +1-312-9087275 .

E-mail address: wangz@northwestern.edu (Z. Wang).

1 These two authors contributed equally to the work. and encodes a 185-a.a. preprohormone (Kitamura et al., 1993b). The preproAM is enzymatically processed to yield two C-terminal amidated bioactive peptides, AM and pro-AM N-terminal 20 peptide (PAMP). AM consists of 52-amino acids in human and 50 in rat, whereas PAMP has only 20 amino-acid residues in both species. Structurally, AM belongs to a peptide family that includes calcitonin gene-related peptide (CGRP) and amylin (Muff et al., 1995). Both rat (rAM) and human AM (hAM) contain a disulfide cysteine-tocysteine bond forming a six-membered amino acid ring structure. The amino acid sequence of AM peptide is highly conserved evolutionarily.

The expression of AM has been detected in a variety of mammalian cells and organs, both in normal and in 
malignant settings (Montuenga et al., 1998). Although $\mathrm{AM}$ and PAMP are derived from the same precursor, they are not always expressed in the same cell types. A new splicing mechanism recently described may explain the differential distribution of AM and PAMP among organs and cell types (Martinez et al., 2001). Both AM and PAMP are present in plasma (Kitamura et al., 1994a; Washimine et al., 1994) and were initially described for their hypotensive activity and their ability to elevate cAMP (Kitamura et al., 1994b, 1993a). In the last few years, many other functions have been attributed to these peptides, including bronchodilation (Kanazawa et al., 1994), antibacterial action (Walsh et al., 1996), and control of hormonal secretion (Martinez et al., 1996). Furthermore, AM has been reported to act as a cell growth regulator (Miller et al., 1998). It stimulates the growth in some types of cells (Andreis et al., 2000; Cornish et al., 1997; Kapas et al., 1997; Moody et al., 2000; Udono et al., 2000), but suppresses cell growth in others (Ando et al., 1997; Chini et al., 1995; Tsuruda et al., 1999). AM and its receptors are expressed during fetal development, in a variety of tumors, and in several cancer cell lines, suggesting an autocrine/paracrine role of this peptide in the control of growth and tumorigenesis (Martinez et al., 1997a,b; Miller et al., 1996; Montuenga et al., 1997). On the other hand, PAMP has been only reported to inhibit the proliferation of human neuroblastoma cells (Ando et al., 1997).

Many of the biological actions of AM and PAMP are mediated through $\mathrm{G}$ protein-coupled receptors (Iwasaki et al., 1996; Kato et al., 1995; Kitamura et al., 1994a). The activation of these receptors leads to the activation of adenyl cyclase and protein kinase A (PKA). The elevation of cAMP is a major step in the signal transduction pathway activated by AM. AM can also influence many other signaling steps such as calcium signaling (Szokodi et al., 1998), cGMP (Ali et al., 2000), $\mathrm{K}^{+}$-ATP channels (Terata et al., 2000), c-fos gene expression (Sato and Autelitano, 1995), and MAPK (Iwasaki et al., 1998; Parameswaran et al., 1999).

Using a PCR-based cDNA subtraction method, we have identified AM as an androgen-response gene on the basis of its induction in the regressed rat ventral prostate by androgen replacement (Wang et al., 1997). Further studies showed that AM mRNA is localized to the prostatic epithelium and the level of its expression is directly and markedly regulated by androgen manipulation (Pewitt et al., 1999). AM peptide has been also detected in the human prostate epithelium (Jiménez et al., 1999). These observations suggest that the AM gene may play an important role in the prostate and/or prostate cancer progression.

In an attempt to address its role in the prostate, we characterized the effect of ectopic expression of the AM gene on PC3 cells. Since its isolation in 1977 by Kaighn et al. (1979), PC3 cell line has been widely used as an in vitro model of the androgen-independent prostate cancer in humans. In this paper we report the effect of the AM gene overexpression on anchorage-dependent and -independent cell proliferation, tumorigenicity in vivo, and cell cycle distribution in the PC 3 model. The results strongly suggest that AM could function as a potent growth inhibitor of prostate cancer cells.

\section{Materials and methods}

\subsection{Cell culture}

PC3 cells were purchased from the American Type Culture Collection (Rockville, MD). Cells were routinely maintained in RPMI 1640 medium containing 10\% fetal bovine serum (FBS), penicillin $(100 \mathrm{U} / \mathrm{ml})$, streptomycin $(100 \mu \mathrm{g} / \mathrm{ml})$ and $2 \mathrm{mM}$ L-glutamine (all from Gibco BRL, Rockville, MD). Cells were cultured in a humidified incubator at $37{ }^{\circ} \mathrm{C}$ in the presence of $5 \%$ $\mathrm{CO}_{2}$.

\section{2. $p c D N A 3.1 /$ Hygro expression vectors and transfections}

The full-length cDNA of the rAM gene was isolated from a $\lambda Z A P$ cDNA phage library constructed from normal rat ventral prostate mRNA. The fragment was cloned into pcDNA3.1/Hygro mammalian expression vector (Invitrogen, Carlsbad, CA) at Eco RV and $X b a \mathrm{I}$ sites. The insert of the plasmid was sequenced using ALFexpress automated sequencing machine (Amersham Biosciences, Piscataway, NJ). Stable transfection experiments of the vector containing the AM gene and the empty vector were carried out using LIPOFECTAMINE $^{\mathrm{TM}}$ according to the protocol provided by the manufacturer (Gibco BRL, Rockville, MD). The cells were diluted and placed under selection $24 \mathrm{~h}$ after transfection with RPMI 1640 medium containing 150 $\mu \mathrm{g} / \mathrm{ml}$ hygromycin B (Invitrogen, Carlsbad, CA). Several individual clones were randomly chosen to study the AM gene expression. Finally, three AM-transfected and two empty vector-transfected PC3 sublines were tested to reduce clonal variations.

\subsection{RNA isolation and Northern blot analysis}

Total RNA was isolated by guanidinium/ $\mathrm{CsCl}$ gradient method (Chirgwin et al., 1979). Purified RNA samples were fractionated by electrophoresis through $1.4 \%$ formaldehyde-agarose gels, capillary transferred overnight to nylon membrane (MAGNA, Micron Separations Inc., Westborough, MA, USA) and then cross-linked to the membrane by UV irradiation. Labeled probes were prepared using random hexamer oligonucleotide priming in the presence of $\alpha{ }^{32} \mathrm{P}$-deox- 
ycytidine triphosphate. Full-length cDNA of approximately $1.4 \mathrm{~kb}$ was used as the template in the probe labeling reaction. Northern blot hybridization was performed overnight at $42{ }^{\circ} \mathrm{C}$ in a buffer containing $5 \times$ SSPE, $2 \times$ Denhardt's solution, $0.1 \%$ SDS, $50 \mu \mathrm{g} /$ $\mathrm{ml}$ denatured salmon sperm DNA, and 50\% formamide. Blots were first washed once at $42{ }^{\circ} \mathrm{C}$ for $30 \mathrm{~min}$, with an excess of wash buffer consisting of $1 \times \mathrm{SSC}$ and $0.1 \%$ SDS and then three times at $65{ }^{\circ} \mathrm{C}$ for $30 \mathrm{~min}$, with $0.2 \times$ SSC and $0.1 \%$ SDS.

\subsection{AM measurement}

Peptides were extracted from the conditioned media using reverse-phase Sep-Pak C-18 cartridges (Waters, Milford, MA, USA) as previously reported (Lewis et al., 1998; Martinez et al., 1999). Briefly, $1 \mathrm{ml}$ of conditioned media was mixed with an equal volume of PBS containing $0.1 \%$ alkali-treated casein and $0.1 \%$ Triton X-100, pH 7.4. Cartridges were activated with $80 \%$ methanol and washed with $0.9 \% \mathrm{NaCl}$. Samples were applied to the columns and, after washing twice with $0.9 \% \mathrm{NaCl}$, AM was eluted with $80 \%$ isopropanol containing 125 $\mathrm{mM} \mathrm{HCl}$. Extracts were freeze-dried to remove the organic solvent. The concentration of both hAM and rAM was measured by RIA analysis, as previously described (Lewis et al., 1998). In brief, extracts were reconstituted in $0.4 \mathrm{ml}$ of RIA buffer $(10 \mathrm{mM}$ phosphate, $50 \mathrm{mM}$ EDTA, $135 \mathrm{mM} \mathrm{NaCl}, 5 \mathrm{mM} \mathrm{NaHCO}$, $0.05 \%$ Triton $\mathrm{X}-100,0.1 \%$ Tween-20, $0.1 \%$ alkali-treated casein, $\mathrm{pH}$ 7.4). A volume of $0.1 \mathrm{ml}$ of sample or standard AM (Phoenix Pharmaceuticals, Mountain View, CA) was preincubated for $18 \mathrm{~h}$ at $4{ }^{\circ} \mathrm{C}$ with 0.1 $\mathrm{ml}$ of primary antibody. After that, $0.1 \mathrm{ml}$ of ${ }^{125} \mathrm{I}-\mathrm{AM}$ (Phoenix Pharmaceuticals, Mountain View, CA) was added $(10,000 \mathrm{cpm})$ and the mixture was incubated at $4{ }^{\circ} \mathrm{C}$ for $18 \mathrm{~h}$. Bound tracer was separated by polyethylene glycol-facilitated precipitation with goat antirabbit serum and normal rabbit serum. The supernatant was aspirated and the radioactivity in the pellet determined by a gamma counter.

\subsection{Cell proliferation}

Cells at $1 \times 10^{3}$ per well were plated in triplicates in 24-well culture plates with complete media. After 5 days, the medium was removed and cells were allowed to detach in the presence of $0.5 \mathrm{ml}$ of $0.05 \%$ trypsin $/ 0.53$ mM EDTA (Gibco BRL, Rockville, MD). Trypsin was neutralized with $2 \mathrm{ml}$ of complete medium. $0.5 \mathrm{ml}$ of the mixture was added to $9.5 \mathrm{ml}$ of isotonic solution (Isoton II, Coulter Corp., Hialeah, FL) and cells were counted using Coulter counter (ZF, Coulter Corp., Hialeah, FL).

\subsection{Anchorage independent growth in soft agar}

Soft agar experiments were performed in six-well plates using $1 \times 10^{4}$ cells $/ \mathrm{ml}$ per well. The bottom layer contained $2 \mathrm{ml}$ of $0.6 \%$ Noble agar (DIFCO, Becton Dickinson, Sparks, MD), penicillin (100 U/ml), streptomycin $(100 \mu \mathrm{g} / \mathrm{ml}), 10 \%$ FBS and $150 \mu \mathrm{g} / \mathrm{ml}$ hygromycin $\mathrm{B}$ in RPMI 1640 medium. The top layer contained $1 \mathrm{ml}$ of $0.3 \%$ Noble agar, penicillin $(100 \mathrm{U} / \mathrm{ml})$, streptomycin $(100 \mu \mathrm{g} / \mathrm{ml}), 10 \%$ FBS, hygromycin B $(150 \mu \mathrm{g} / \mathrm{ml})$ and $1 \times 10^{4}$ cells. Parental PC 3 cells were cultured in the same conditions but without hygromycin $\mathrm{B}$. Plates were incubated for 2 weeks at $37{ }^{\circ} \mathrm{C}$ with $5 \% \mathrm{CO}_{2}$ to allow cell proliferation in soft agar. Representative photographs were taken with a Leica phase contrast microscope. Volumes of the colonies were calculated from the average radius of randomly selected colonies by image analysis (analySYS ${ }^{\circledR} 3.0$ software, Soft Imaging System $\mathrm{GmbH}$, Munster, Germany).

\subsection{Cell cycle analysis}

Flow cytometry analysis was performed to examine the DNA content in each cell cycle phase. Transfectants and parental PC3 cells were incubated with growth medium in triplicate T25 flasks for $36 \mathrm{~h}$. After this time, cells were detached using $0.05 \%$ trypsin $/ 0.53 \mathrm{mM}$ EDTA. One million cells in each sample were treated with $1 \mathrm{ml}$ of the staining solution containing $50 \mu \mathrm{g} / \mathrm{ml}$ propidium iodide (Molecular Probes, Inc., Eugene, OR), $0.1 \%$ Triton-X, $3.5 \mathrm{mM}$ citrate buffer, $3 \%$ polyethylene glycol and 180 units/ml RNase A (Worthington Biochemical Corp., Lakewood, NY). After $20 \mathrm{~min}$ of incubation at $37{ }^{\circ} \mathrm{C}$, an equal volume of salt solution was added $(50 \mu \mathrm{g} / \mathrm{ml}$ propidium iodide, $0.1 \%$ Triton-X, $3.75 \mathrm{M} \mathrm{NaCl}$ and $3 \%$ polyethylene glycol). Cells were stored overnight at $4{ }^{\circ} \mathrm{C}$ prior to analysis at an excitation wavelength of $488 \mathrm{~nm}$ in a Beckman Coulter Epics XL-MCL flow cytometer with System II software (Beckman Coulter, Miami, FL, USA). Cell cycle data were obtained using Modfit (v5.2) software (Verity Software House, MN).

\subsection{Subcutaneous xenograft tumor in nude mice}

Tumorigenicity of AM gene overexpressing sublines AM17 and AM15 was analyzed in BALB/c strain athymic nude mice (4-week old males). Mice were injected subcutaneously with $1 \times 10^{6}$ cells in $0.2 \mathrm{ml}$ of complete media. Controls include the empty vectortransfected Mock2 and parental PC3 cells. Each mouse was injected in two sites above both forearms. Tumor sizes were measured every week and volumes were calculated using the $V=\left(w^{2} \times l\right) / 2$ formula, as previously described (Euhus et al., 1986). 


\subsection{Statistical analysis}

All of the statistical analyses were conducted using the Student's $t$-test (two-tailed). The SPSS 10.0 software package (SPSS Inc., Chicago, IL) was used to perform these calculations. Differences were considered statistically significant if $P<0.05$ and very significant if $P<$ 0.01 .

\section{Results}

\subsection{Transfected AM cDNA is expressed in PC3 cells}

The rAM cDNA was cloned into pcDNA3.1/Hygro mammalian expression vector, sequenced and then transfected into PC3 prostate cancer cells. The cloned fragment showed a single nucleotide change in its sequence when compared to other rat preproAM sequences deposited in GenBank. A cytosine in the previously described sequences is substituted by a thymine that leads to alteration in one amino acid residue in the preproAM sequence (T26I). The substitution is likely due to polymorphism in the rat preproAM sequence. The variation is located in the non-conserved $\mathrm{N}$-terminal region of the PAMP, which is believed to be non-essential for PAMP function (Mahata et al., 1998). Human and pig sequences contain a valine instead of a threonine in that position and thus it is not a wellconserved amino acid residue.

After selection of stably transfected PC3 sublines, the expression of the rAM transgene in various sublines was assessed by Northern blot. Rat AM mRNA expression was observed only in clones transfected with the rAM expression vector (Fig. 1). The rAM cDNA probe did

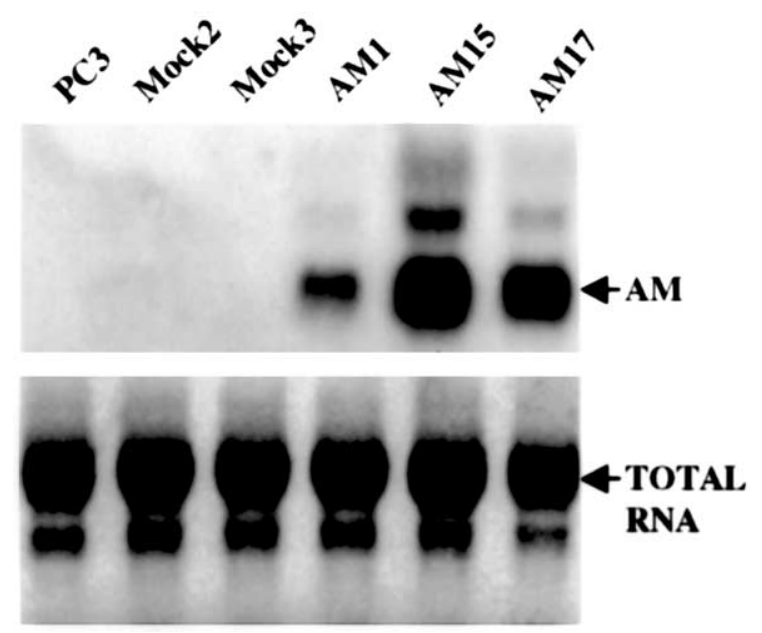

Fig. 1. Northern blot analysis of AM transgene expression in transfected PC3 clones. The mRNA derived from the AM transgene migrates at $1.6 \mathrm{~kb}$ position (upper panel). Ten micrograms of total RNA was loaded in each line. The methylene blue staining of the total RNA is indicated (lower panel). not detect the endogenous hAM mRNA in PC3 parental or pcDNA3.1 empty vector-transfected cells since the hybridization was performed with the rat probe at high stringency conditions. Longer exposure of the film revealed a faint band corresponding to hAM mRNA in parental line and empty vector transfected sublines (data not shown). As shown in Fig. 1, rAM-transfected clones AM1, AM15 and AM17 expressed considerable levels of rAM mRNA. The expression level of the rAM mRNA differs between the three rAM expressing clones. The AM15 subline showed the highest expression, followed by AM17. AM1 subline exhibited the lowest expression among the rAM gene transfected clones.

To determine whether rAM peptide was secreted into the medium of the transfected sublines, RIA analysis was carried out using two different antibodies, one for hAM and another for rAM, to detect the endogenous and ectopic expression of AM, respectively. Table 1 shows that parental PC3 cells expressed basal levels of hAM $\left(16.01 \pm 1.61 \mathrm{pg} / \mathrm{ml} / 10^{6}\right.$ cells $)$. Expression of the AM transgene in AM1, AM15 and AM17 caused a considerable increase of rAM peptide levels in the medium with an average of $224.8 \pm 25.8 \mathrm{pg} / \mathrm{ml} / 10^{6}$ cells. The AM15 clone has the highest secretion of rAM, followed by AM17 and AM1. No cross-reactivity was observed between the antibodies against hAM and rAM. The RIA results are consistent with the Northern blot results; clones with a higher AM mRNA expression have also a higher peptide expression.

\subsection{AM gene overexpression inhibits PC3 cell proliferation in culture}

The effect of AM gene overexpression on cell proliferation was tested in a 5-day proliferation assay. The parental PC3 line, the three rAM transgene expressing clones, and the two empty vector transfected sublines were used in the assay. Fig. 2 shows that there was a very significant difference between parental PC3

Table 1

AM peptide levels in conditioned medium

\begin{tabular}{lrc}
\hline Cell line & rAM $\left(\mathrm{pg} / \mathrm{ml} / 10^{6} \text { cells }\right)^{\mathrm{a}}$ & hAM $\left(\mathrm{pg} / \mathrm{ml} / 10^{6} \text { cells }\right)^{\mathrm{b}}$ \\
\hline No cells & $0.030 \pm 0.128$ & $-0.051 \pm 0.064$ \\
PC3 & $0.991 \pm 0.323$ & $16.01 \pm 1.61$ \\
Mock2 & $-0.182 \pm 0.351$ & $0.109 \pm 0.05$ \\
AM1 & $141.8 \pm 26.79$ & $8.873 \pm 0.24$ \\
AM15 & $325.8 \pm 45.07$ & $0.662 \pm 0.032$ \\
AM17 & $206.8 \pm 5.515$ & $4.481 \pm 1.701$
\end{tabular}

AM levels were measured with RIA as previously described (Lewis et al., 1998). Two different antibodies, one specific for rAM and another for hAM, were used in order to discriminate between endogenous and transfected AM expression. Results are shown with mean \pm SEM.

${ }^{a}$ Using primary antibody against rAM.

${ }^{b}$ Using primary antibody against hAM. 


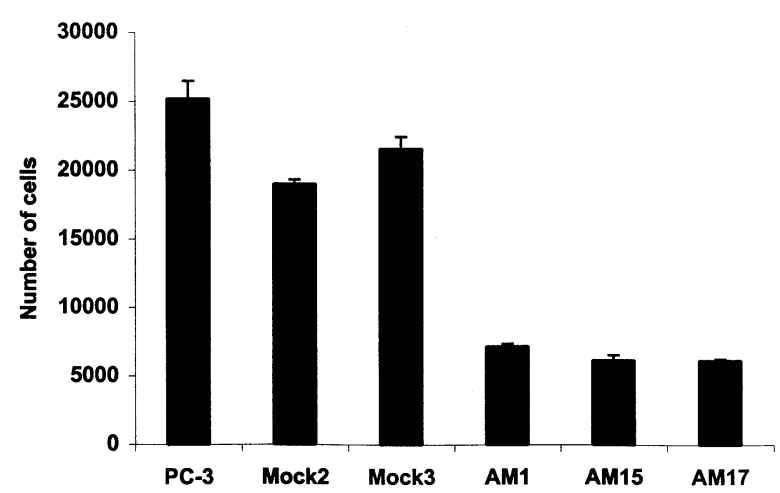

Fig. 2. The effect of AM gene overexpression on PC3 cell proliferation assay in culture dishes. Cells were plated at $1 \times 10^{3}$ cells/well and allowed to grow 5 days before counting. Data shown here are from a representative experiment repeated three times with similar results. Bars denote SEM.

cells and sublines with AM overexpression $(P<0.01)$. After 5 days of culture, a $75 \%$ decrease in the number of cells was found in clones overexpressing AM, compared to parental PC3 cells. Clones transfected with the empty vector showed a small reduction in growth rates $(P<$ 0.05), which may reflect clonal variations. However, growth inhibition due to AM overexpression was much more dramatic than that caused by the transfection of the empty vector. These results indicate that AM overexpression significantly inhibits anchorage-dependent growth of PC3 cells.

To further investigate the impact of the AM gene overexpression on PC3 cells, we tested the effect of AM gene overexpression on anchorage-independent growth in soft agar. Fig. 3A shows that PC3 cells transfected with AM gene developed significantly fewer colonies than parental cells or empty vector-transfected cells. Thus, AM transfection caused a reduction in the number of colonies growing in soft agar. The pictures also showed that PC3 cells with AM gene overexpression developed smaller colonies than controls. In order to quantify the colony sizes, randomly taken pictures were studied by image analysis, as described in Section 2 (Fig. 3B). There was no statistically significant difference between the parental PC3 and mock-transfected colony sizes $(P>0.05)$, while AM expressing clones were significantly smaller than control clones $(P<0.01)$. Parental PC3 colonies had an average volume of $72.32 \pm$ $14.78 \mu^{3}$, while the average of AM-expressing clones (AM1, AM15 and AM17) was $6.453 \pm 0.820 \mu^{3}$. Moreover, as observed in the anchorage-dependent proliferation assays, the extent of colony growth inhibition was higher for AM15 and AM17 clones than for AM1 $(P<0.01)$. These results indicate that AM overexpression caused a very significant reduction of colony sizes growing in soft agar and that there is an inverse correlation between expression level of rAM gene and the size of these colonies (size of the colonies: AM15 <
AM17 < AM1; expression of rAM gene: AM15 > AM17 > AM1).

\subsection{AM gene overexpression induces $G_{0} / G_{1}$ cell cycle arrest in PC3 cells}

To determine whether AM overexpression inhibits proliferation via cell cycle arrest, we conducted a flow cytometry analysis of parental, empty vector- and the AM-transfected PC3 cells. The results (Fig. 4) showed that approximately $66 \%$ of the AM-transfected cells were in the $G_{0} / G_{1}$ phase, whereas only about $50 \%$ of the parental PC3 and empty-vector transfected cells were in the $\mathrm{G}_{0} / \mathrm{G}_{1}$ phase. This difference was statistically very significant $(P<0.01)$. There was no statistical difference in cell cycle progression between parental PC 3 cells and empty vector transfected cells $(P>0.05)$. As a result of $\mathrm{G}_{0} / \mathrm{G}_{1}$ arrest, $A M$ gene overexpression also caused a decrease in the percentage of cells in $S$ and $\mathrm{G}_{2} / \mathrm{M}$ phases. These results indicate that overexpression of the AM gene induces $G_{0} / G_{1}$ growth arrest in PC 3 cells.

\subsection{AM gene overexpression inhibits PC3 xenograft tumor growth}

The fact that the AM-transfected cells grew less aggressively in soft agar suggested that these cells might also have reduced ability to form tumors in nude mice. To test whether AM gene overexpression inhibits prostate tumor growth in vivo, subcutaneous xenograft tumors were generated using AM15 and AM17 sublines, Mock2, and parental PC3 cells. As shown in Fig. 5, the growth rates of AM15 and AM17 xenograft tumors were much slower than those of Mock2 and parental PC3 xenografts in nude mice. The size of tumors of empty vector transfected and parental PC 3 cells after 5 weeks were similar $\left(780 \mathrm{~mm}^{3}\right.$ approximately). In contrast, the size of tumors for clones AM15 and AM17 tumors was much smaller (around $200 \mathrm{~mm}^{3}$ ). Thus, AM gene overexpression also inhibited PC3 cell growth in vivo, as demonstrated by a reduction in the tumor volume and growth rate.

\section{Discussion}

$\mathrm{AM}$ is a pluripotent peptide hormone expressed in many tissues and cell lines. AM gene was recently shown to express abundantly in the rat ventral prostate, suggesting that AM may play an important role in the prostate (Pewitt et al., 1999; Wang et al., 1997). The potential significance of AM gene in the prostate was further substantiated by detecting AM gene products, AM and PAMP, in normal human and rat prostate (Jiménez et al., 1999). The present study showed for the first time that overexpression of the rAM gene inhibited 

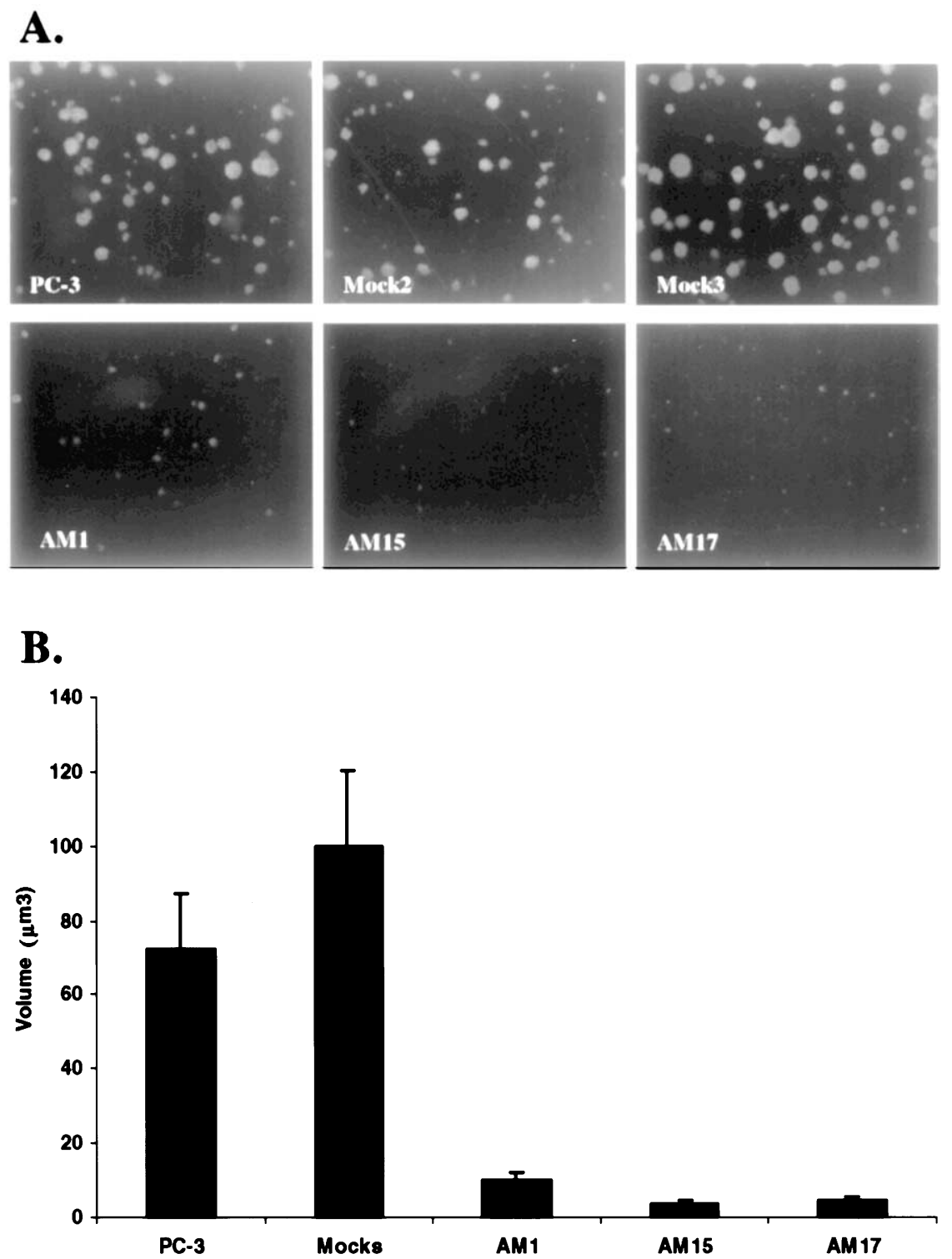

Fig. 3. The effect of AM gene overexpression on anchorage-independent growth of PC3 cells in soft agar. Cells $\left(1 \times 10^{4}\right)$ were seeded in $0.3 \%$ top agarose on $0.6 \%$ base agar as described in Section 2. (A) Photographs of the colonies were taken after 2 weeks of growth with $4 \times$ objective lens on a phase contrast microscope. (B) Average volumes of the colonies were calculated using the formula $V=3 / 4 \pi r^{3}$ based on the diameters obtained by digital analysis (analySYS ${ }^{\circledR} 3.0$ software). Bars denote SEM.

significantly the anchorage-dependent and -independent growth as well as in vivo tumor growth in the PC3 prostate cancer cell model. Our observations strongly suggest an involvement of the AM gene in the regulation of prostate growth and prostate cancer progression.

We have stably transfected PC3 cells with the rAM cDNA expression vector and isolated three AM overexpressing clones for characterization in this study. The expression of transfected rAM cDNA was characterized by Northern blot and RIA analysis. Northern blot showed rAM mRNA overexpression in the three clones, while RIA detected rAM peptide secretion in the cultured media. The levels of rAM mRNA in stablytransfected PC3 sublines correlated with the amount of
rAM secreted in culture media. Transfection of rAM instead of hAM allowed us to discriminate endogenous from ectopic AM expression. Using the antibody against hAM, RIA assay demonstrated that parental PC3 cells secreted a small amount of endogenous AM peptide into the culture medium $\left(16.01 \pm 1.61 \mathrm{pg} / \mathrm{ml} / 10^{6}\right.$ cells $)$. The endogenous AM expression level we observed is similar to those previously described for PC3 cells (Rocchi et al., 2001) and other cancer cell lines (Nakayama et al., 1998; Takahashi et al., 1998). In our experiment, AM gene transfection led to a marked increase in the amount of AM peptide secreted to the medium, as determined by RIA using antibodies specific for rAM. Rat AM has been previously described to bind functional hAM 


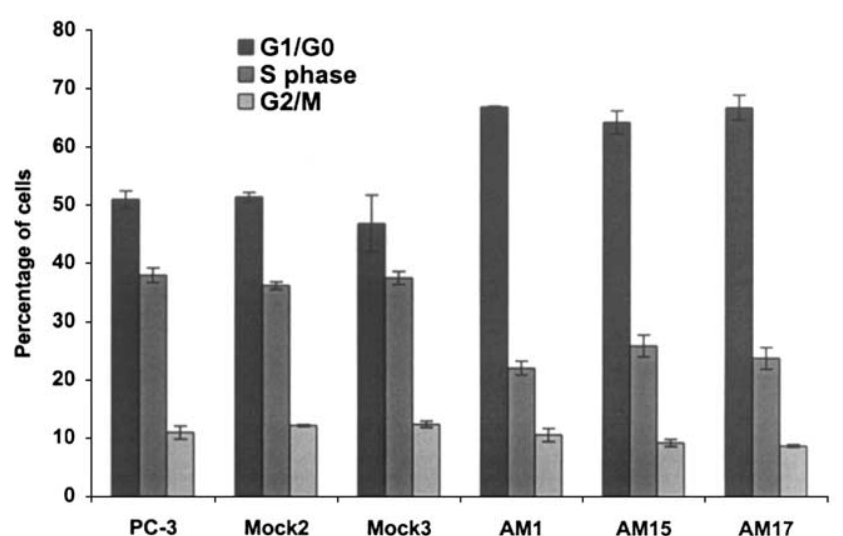

Fig. 4. Effect of AM gene overexpression on PC3 cell cycle assayed by flow cytometry. Triplicate flasks of each cell subline were grown $36 \mathrm{~h}$ under the same conditions and harvested before reaching confluence. One million cells were stained with propidium iodide $(50 \mu \mathrm{g} / \mathrm{ml})$ overnight at $4{ }^{\circ} \mathrm{C}$ prior to flow cytometry analysis. Data shown are mean cell percentage values of one single experiment calculated using Modifit computer software. Similar results were obtained in two other independent experiments. Bars denote SEM.

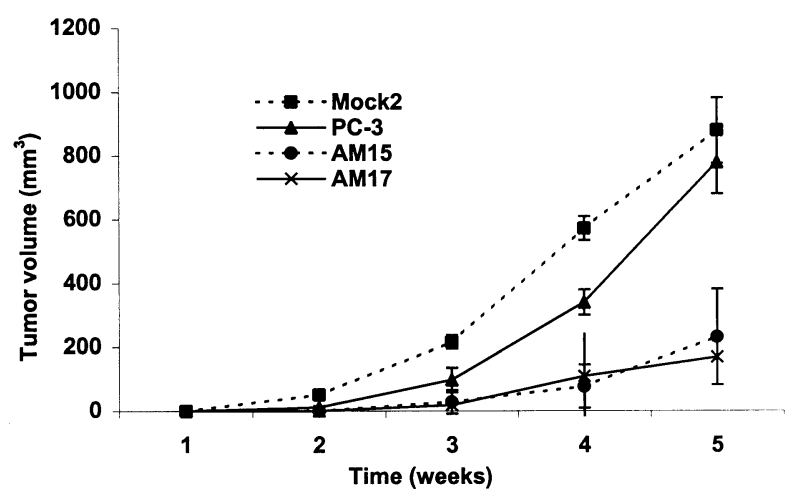

Fig. 5. Effect of AM gene overexpression on PC3 xenograft tumor growth in nude mice. Parental PC3, Mock2, AM15, and AM17 cells $\left(1 \times 10^{6}\right)$ were injected subcutaneously behind the forearms. Tumor volume $\left(\mathrm{mm}^{3}\right)$ was estimated by the formula described in Section 2 . Data shows the mean \pm SEM in duplicate results.

receptor complexes with an $\mathrm{IC}_{50}$ of $0.75 \mathrm{nM}$ (McLatchie et al., 1998). The conditioned media of the AM gene transfected clones contained an average of $0.959 \pm 0.113$ $\mathrm{nM}\left(224.8 \pm 25.79 \mathrm{pg} / \mathrm{ml} / 10^{6}\right.$ cells $)$ of rAM peptide. The reported binding affinity for ${ }^{125} \mathrm{I}-\mathrm{AM}$ to its receptors varies from 0.17 to $13 \mathrm{nM}$ (Hinson et al., 2000) depending on the cell types. The levels of secreted AM in our transfected clones are thus in the range required for efficient AM receptor activation.

Several receptors have been described for AM. One of these receptors, L1, was shown to bind selectively to AM with high affinity and does not interact with CGRP (Kapas et al., 1995). The other two reported receptors, RDC1 and calcitonin receptor-like receptor (CRLR), bind to AM with lower affinities relative to $\mathrm{L} 1$, and interact with the related peptide CGRP with higher affinities (Hall et al., 1995; Kapas and Clark, 1995). Interestingly, CRLR requires the presence of modulating factors known as receptor activity modifying proteins (RAMPs) (McLatchie et al., 1998). Although there are no published studies on AM receptors in the prostate cancer or in prostate cell lines, we have recently found the specific AM receptor (L1) by RT-PCR in PC3 cells (data not shown). More studies are needed to clarify whether other types of AM receptors are also present in prostate cell lines.

The expression of ectopic AM cDNA significantly inhibited the proliferation of transfected clones in vitro. A positive correlation was observed between rAM expression levels and the extent of growth inhibition among different clones under both anchorage-dependent and -independent conditions. Furthermore, the inhibitory effect of AM overexpression in PC3 cells was also observed in vivo, since mice injected with AM15 and AM17 cells developed very small tumors relative to the controls. These observations argue that the AM gene has the potential to play an important role in growth control of the normal and cancerous prostate.

The mechanism by which AM gene overexpression inhibits the growth of prostate cancer cells could be complex. We have tried an in vitro dose-response study using commercially available AM peptide with PC3 cells. We have repeated the experiments several times and no significant inhibitory effect was observed (data not shown). Two possible explanations exist. First, the half-life of AM peptide is short, about $30 \mathrm{~min}$ (Hinson et al., 2000). Dramatic growth inhibition may require continuous presence of AM, which can be achieved conveniently by ectopic expression of the AM gene but not by treating cells with AM peptide. Second, AM gene encodes preproAM, which can be processed to generate several small peptides including AM, PAMP, proAM $\mathrm{A5}_{4-92}$, and adrenotensin (Kitamura et al., 1993b, 1994b; Gumusel et al., 1995, 1996). It is possible that AM, PAMP, proAM $45-92$, and/or adrenotensin may work together to inhibit cell growth. Mutagenesis studies will be needed to determine the region in the preproAM critical for the growth inhibition.

Growth related functions of AM and PAMP peptides are mainly associated with intracellular cAMP elevation after AM/PAMP ligand-receptor interaction. PC3 is a hormone-refractory human prostate carcinoma line that is markedly growth inhibited by cAMP (Bang et al., 1992). Thus, cAMP elevation could be involved in the growth inhibition of PC3 cells by AM gene overexpression. Further research addressing the signaling pathways involved in this growth inhibition will be crucial for understanding the mechanism of AM gene action.

The growth inhibition by the AM gene overexpression in PC 3 cells is due, at least in part, to the $G_{0} / G_{1}$ cell cycle arrest. The AM gene overexpression increases the percentage of cells in the $\mathrm{G}_{0} / \mathrm{G}_{1}$ phase and reduces the 
percentage of the cells in $\mathrm{S}+\mathrm{G}_{2} / \mathrm{M}$ phases, reflecting the inhibition of the cells to undergo mitosis. It is well known that prostate cancer progresses from a welldifferentiated stage to a poorly-differentiated state. This progression is accompanied with a shift in the distribution of cells from the $G_{0} / G_{1}$ phase towards the $S$ and $G_{2} /$ M phases (Neill et al., 1989). AM transgene overexpression in PC3 cells reversed this shift towards $\mathrm{G}_{0} /$ $G_{1}$, suggesting that the effect of $A M$ in prostate cancer may be mediated through cell cycle control.

The growth alterations caused by AM may vary depending on the genetic background of the receptive cell. AM stimulates growth in osteoblasts (Cornish et al., 1997), oral keratinocytes (Kapas et al., 1997), adrenal cells (Andreis et al., 2000), retinal pigment epithelial cells (Udono et al., 2000) and teratocarcinoma cells (Moody et al., 2000), and suppresses growth in cardiac fibroblasts (Tsuruda et al., 1999), mesangial (Chini et al., 1995) and neuroblastoma (Ando et al., 1997) cells. Interestingly, both proliferative (Iwasaki et al., 1998) and antiproliferative (Kano et al., 1996) actions have been reported for AM in smooth muscle cells, depending on the culture conditions.

The inhibition of prostate cancer cell growth by AM gene overexpression may not be limited to PC3 cell line. We have tried twice to stably transfect LNCaP human prostate cancer cells with the same rAM expression vector. However, we were unable to establish LNCaP sublines with AM gene overexpression. This observation suggests that rAM overexpression is detrimental to LNCaP cells.

In summary, this study showed that AM gene overexpression significantly inhibited the growth of the PC3 human prostate cancer cell line in vivo and in vitro, possibly through the $\mathrm{G}_{0} / \mathrm{G}_{1}$ checkpoint. Elucidating the mechanism of AM gene inhibition of prostate cancer growth may lead to novel approaches for prostate cancer treatment.

\section{Acknowledgements}

We thank Jomol Cyriac, Mahesh Alur, Feng Jiang, Shane Oram, and Qiuheng Zhang for critical reading of the manuscript. We also thank Mary Paniagua and the staff from the Northwestern University Flow Cytometry Facility for their assistance in the cell cycle analyses. This work was supported in part by NIH R01 DK51193, NIH P50 CA90386 Prostate Cancer SPORE, and Boehringer Ingelheim International GmbH. I.A. and L.M.M. were partially funded by Spanish Ministry of Education (CICYT PB98-0211) and Fundación Echebano. I.A. was the recipient of a Fullbright Commission grant.

\section{References}

Ali, N., Yousufzai, S.Y., Abdel-Latif, A.A., 2000. Activation of particulate guanylate cyclase by adrenomedullin in cultured SV40 transformed cat iris sphincter smooth muscle SV-CISM-2 cells. Cell Signal 12, 491-498.

Ando, K., Omi, N., Shimosawa, T., Fujita, T., 1997. Proadrenomedullin N-terminal 20 peptide PAMP inhibits proliferation of human neuroblastoma TGW cells. FEBS Lett. 413, 462-466.

Andreis, P.G., Markowska, A., Champion, H.C., Mazzocchi, G., Malendowiz, L.K., Nussdorfer, G.G., 2000. Adrenomedullin enhances cell proliferation and deoxyribonucleic acid synthesis in rat adrenal zona glomerulosa: receptor subtype involved and signaling mechanism. Endocrinology 141, 2098-2104.

Bang, Y.J., Kim, S.J., Danielpour, D., Ma, O.R., Kim, K.Y., Myers, C.E., Trepel, J.B., 1992. Cyclic AMP induces transforming growth factor beta 2 gene expression and growth arrest in the human androgen-independent prostate carcinoma cell line PC-3. Proc. Natl. Acad. Sci. USA 89, 3556-3560.

Chini, E.N., Choi, E., Grande, J.P., Burnett, J.C., Dousa, T.P., 1995. Adrenomedullin suppresses mitogenesis in rat mesangial cells via cAMP pathway. Biochem. Biophys. Res. Commun. 215, 868-873.

Chirgwin, J.M., Przybyla, A.E., MacDonald, R.J., Rutter, W.J., 1979. Isolation of biologically active ribonucleic acid from sources enriched in ribonuclease. Biochemistry 18, 5294-5299.

Cornish, J., Callon, K.E., Coy, D.H., Jiang, N.Y., Xiao, L., Cooper, G.J., Reid, I.R., 1997. Adrenomedullin is a potent stimulator of osteoblastic activity in vitro and in vivo. Am. J. Physiol. 273, E1113-E1120.

Euhus, D.M., Hudd, C., LaRegina, M.C., Johnson, F.E., 1986. Tumor measurement in the nude mouse. J. Surg. Oncol. 31, 229-234.

Gumusel, B., Chang, J.K., Hyman, A., Lippton, H., 1995. Adrenotensin: an ADM gene product with the opposite effects of ADM. Life Sci. 57, L87-L90.

Gumusel, B., Chang, J.K., Hao, Q., Hyman, A., Lippton, H., 1996. Adrenotensin: an adrenomedullin gene product contracts pulmonary blood vessels. Peptides 17, 461-465.

Hall, J.M., Siney, L., Lippton, H., Hyman, A., Kang-Chang, J., Brain, S.D., 1995. Interaction of human adrenomedullin 13-52 with calcitonin gene-related peptide receptors in the microvasculature of the rat and hamster. Br. J. Pharmacol. 114, 592-597.

Hinson, J.P., Kapas, S., Smith, D.M., 2000. Adrenomedullin, a multifunctional regulatory peptide. Endocr. Rev. 21, 138-167.

Iwasaki, H., Eguchi, S., Shichiri, M., Marumo, F., Hirata, Y., 1998. Adrenomedullin as a novel growth-promoting factor for cultured vascular smooth muscle cells: role of tyrosine kinase-mediated mitogen-activated protein kinase activation. Endocrinology 139, $3432-3441$

Iwasaki, H., Hirata, Y., Iwashina, M., Sato, K., Marumo, F., 1996. Specific binding sites for proadrenomedullin N-terminal 20 peptide PAMP in the rat. Endocrinology 137, 3045-3050.

Jiménez, N., Calvo, A., Martinez, A., Rosell, D., Cuttitta, F., Montuenga, L.M., 1999. Expression of adrenomedullin and proadrenomedullin $\mathrm{N}$-terminal 20 peptide in human and rat prostate. J. Histochem. Cytochem. 47, 1167-1178.

Kaighn, M.E., Narayan, K.S., Ohnuki, Y., Lechner, J.F., Jones, L.W., 1979. Establishment and characterization of a human prostatic carcinoma cell line PC-3. Invest. Urol. 17, 16-23.

Kanazawa, H., Kurihara, N., Hirata, K., Kudoh, S., Kawaguchi, T., Tadeka, T., 1994. Adrenomedullin, a newly discovered hypotensive peptide, is a potent bronchodilator. Biochem. Biophys. Res. Commun. 205, 251-254.

Kano, H., Kohno, M., Yasunari, K., Yokokawa, K., Horio, T., Ikeda, M., Minami, M., Hanehira, T., Takeda, T., Yoshikawa, J., 1996. Adrenomedullin as novel antiproliferative factor of vascular smooth muscle cells. J. Hypertens. 14, 209-213. 
Kapas, S., Brown, D.W., Farthing, P.M., Hafi-Pavli, E., 1997. Adrenomedullin has mitogenic effects on human oral keratinocytes: involvement of cyclic AMP. FEBS Lett. 418, 287-290.

Kapas, S., Catt, K.J., Clark, A.J., 1995. Cloning and expression of cDNA encoding a rat adrenomedullin receptor. J. Biol. Chem. 270, $25344-25347$.

Kapas, S., Clark, A.J., 1995. Identification of an orphan receptor gene as a type 1 calcitonin gene-related peptide receptor. Biochem. Biophys. Res. Commun. 217, 832-838.

Kato, J., Kitamura, K., Kangawa, K., Eto, T., 1995. Receptors for adrenomedullin in human vascular endothelial cells. Eur. J. Pharmacol. 289, 383-385.

Kitamura, K., Ichiki, Y., Tanaka, M., Kawamoto, M., Emura, J., Sakakibara, S., Kangawa, K., Matsuo, H., Eto, T., 1994a. Immunoreactive adrenomedullin in human plasma. FEBS Lett. 341, 288-290.

Kitamura, K., Kangawa, K., Ishiyama, Y., Washimine, H., Ichiki, Y., Kawamoto, M., Minamino, N., Matsuo, H., Eto, T., 1994b. Identification and hypotensive activity of proadrenomedullin $\mathrm{N}$ terminal 20 peptide PAMP. FEBS Lett. 351, 35-37.

Kitamura, K., Kangawa, K., Kawamoto, M., Ichiki, Y., Nakamura, S., Matsuo, H., Eto, T., 1993a. Adrenomedullin: a novel hypotensive peptide isolated from human pheochromocytoma. Biochem. Biophys. Res. Commun. 192, 553-560.

Kitamura, K., Sakata, J., Kangawa, K., Kojima, M., Matsuo, H., Eto, T., 1993b. Cloning and characterization of cDNA encoding a precursor for human adrenomedullin. Biochem. Biophys. Res. Commun. 194, 720-725.

Lewis, L.K., Smith, M.W., Yandle, T.G., Richards, A.M., Nicholls, M.G., 1998. Adrenomedullin 1-52 measured in human plasma by radioimmunoassay: plasma concentration, adsorption, and storage. Clin. Chem. 44, 571-577.

Mahata, M., Mahata, S.K., Parmer, R.J., O’Connor, D.T., 1998. Proadrenomedullin N-terminal 20 peptide: minimal active region to regulate nicotinic receptors. Hypertension 32, 907-916.

Martinez, A., Elsasser, T.H., Bhathena, S.J., Pio, R., Buchanan, T.A., Macri, C.J., Cuttitta, F., 1999. Is adrenomedullin a causal agent in some cases of type 2 diabetes? Peptides 20, 1471-1478.

Martinez, A., Hodge, D.L., Garayoa, M., Young, H.A., Cuttitta, F., 2001. Alternative splicing of the proadrenomedullin gene results in differential expression of gene products. J. Mol. Endocrinol. 27, $31-41$.

Martinez, A., Miller, M.J., Catt, K.J., Cuttitta, F., 1997a. Adrenomedullin receptor expression in human lung and in pulmonary tumors. J. Histochem. Cytochem. 45, 159-164.

Martinez, A., Weaver, C., Lopez, J., Bhathena, S.J., Elsasser, T.H., Miller, M.J., Moody, T.W., Unsworth, E.J., Cuttitta, F., 1996. Regulation of insulin secretion and blood glucose metabolism by adrenomedullin. Endocrinology 137, 2626-2632.

Martinez, V., Cuttitta, F., Tache, Y., 1997b. Central action of adrenomedullin to inhibit gastric emptying in rats. Endocrinology 138, 3749-3755.

McLatchie, L.M., Fraser, N.J., Main, M.J., Wise, A., Brown, J., Thompson, N., Solari, R., Lee, M.G., Foord, S.M., 1998. RAMPs regulate the transport and ligand specificity of the calcitoninreceptor-like receptor. Nature 393, 333-339.

Miller, M.J., Martinez, A., Montuenga, L.M., Garayoa, M., Moody, T., Unsworth, E., Cuttitta, F., 1998. Adrenomedullin: a pluripotent peptide with growth regulatory function. In: Martinez, A., Cuttitta, F. (Eds.), Adrenomedullin. IOS Press and Ohmsha, Amsterdam, pp. $171-183$.

Miller, M.J., Martinez, A., Unsworth, E.J., Thiele, C.J., Moody, T.W., Elsasser, T., Cuttitta, F., 1996. Adrenomedullin expression in human tumor cell lines. Its potential role as an autocrine growth factor. J. Biol. Chem. 271, 23 345-23 351.

Montuenga, L.M., Martinez, A., Miller, M.J., Unsworth, E.J., Cuttitta, F., 1997. Expression of adrenomedullin and its receptor during embryogenesis suggests autocrine or paracrine modes of action. Endocrinology 138, 440-451.

Montuenga, L.M., Martínez, A., Miller, M.J., Unsworth, E.J., Cuttitta, F., 1998. Expression of AM and PAMP in normal adult and developing mammals. In: Martínez, A., Cuttitta, F. (Eds.), Adrenomedullin. IOS Press and Ohmsha, Amsterdam, pp. 49-68.

Moody, T.W., Coy, D., Cuttitta, F., Montuenga, L.M., 2000. Proadrenomedullin NH2-terminal 20 peptide PAMP and adrenomedullin bind to teratocarcinoma cells. Peptides 21, 101-107.

Muff, R., Born, W., Fisher, J.A., 1995. Calcitonin, calcitonin generelated peptide, adrenomedullin and amylin: homologous peptides, separate receptors and overlapping biological actions. Eur. J. Endocrinol. 133, 17-20.

Nakayama, M., Takahashi, K., Hara, E., Murakami, O., Totsune, K., Sone, M., Satoh, F., Shibahara, S., 1998. Production and secretion of two vasoactive peptides, endothelin-1 and adrenomedullin, by a colorectal adenocarcinoma cell line, DLD-1. J. Cardiovasc. Pharmacol. 31 (Suppl. 1), S534-S536.

Neill, W.A., Norval, M., Habib, F.K., 1989. Nuclear DNA analysis of prostate tissues: correlation with stage and grade of tumour. Urol. Int. 44, 141-146.

Parameswaran, N., Spielman, W.S., Brooks, D.P., Nambi, P., 1999. SB203580 reverses adrenomedullin's effect on proliferation and apoptosis in cultured mesangial cells. Eur. J. Pharmacol. 371, 7582.

Pewitt, E.B., Haleem, R., Wang, Z., 1999. Adrenomedullin gene is abundantly expressed and directly regulated by androgen in the rat ventral prostate. Endocrinology 140, 2382-2386.

Rocchi, P., Boudouresque, F., Zamora, A.J., Muracciole, X., Lechevallier, E., Martin, P.M., Ouafik, L., 2001. Expression of adrenomedullin and peptide amidation activity in human prostate cancer and in human prostate cancer cell lines. Cancer Res. 61, 11961206.

Sato, A., Autelitano, D.J., 1995. Adrenomedullin induces expression of c-fos and AP-1 activity in rat vascular smooth muscle cells and cardiomyocytes. Biochem. Biophys. Res. Commun. 217, 211-216.

Szokodi, I., Kinnunen, P., Tavi, P., Weckstrom, M., Toth, M., Ruskoaho, H., 1998. Evidence for cAMP-independent mechanisms mediating the effects of adrenomedullin, a new inotropic peptide. Circulation 97, 1062-1070.

Takahashi, K., Satoh, F., Sone, M., Totsune, K., Arihara, Z., Noshiro, T., Mouri, T., Murakami, O., 1998. Expression of adrenomedullin mRNA in adrenocortical tumors and secretion of adrenomedullin by cultured adrenocortical carcinoma cells. Peptides 19, 17191724.

Terata, K., Miura, H., Liu, Y., Loberiza, F., Gutterman, D.D., 2000. Human coronary arteriolar dilation to adrenomedullin: role of nitric oxide and K + channels. Am. J. Physiol. Heart Circ. Physiol. 279, H2620-H2626.

Tsuruda, T., Kato, J., Kitamura, K., Kawamoto, M., Kuwasako, K., Imamura, T., Koiwaya, Y., Tsuji, T., Kangawa, K., Eto, T., 1999. An autocrine or a paracrine role of adrenomedullin in modulating cardiac fibroblast growth. Cardiovasc. Res. 43, 958-967.

Udono, T., Takahashi, K., Nakayama, M., Murakami, O., Durlu, Y.K., Tamai, M., Shibahara, S., 2000. Adrenomedullin in cultured human retinal pigment epithelial cells. Invest. Ophthalmol. Vis. Sci. 41, 1962-1970.

Walsh, T.J., Martínez, A., Peter, J., Miller, M.J., Unsworth, E.J., Cuttitta, F., 1996. Antimicrobial activity of adrenomedullin and its gene-related peptides. Clin. Infect. Dis. 23, 877.

Wang, Z., Tufts, R., Haleem, R., Cai, X., 1997. Genes regulated by androgen in the rat ventral prostate. Proc. Natl. Acad. Sci. USA 94, 12999-13004.

Washimine, H., Kitamura, K., Ichiki, Y., Yamamoto, Y., Kangawa, K., Matsuo, H., Eto, T., 1994. Immunoreactive proadrenomedullin $\mathrm{N}$-terminal 20 peptide in human tissue, plasma and urine. Biochem. Biophys. Res. Commun. 202, 1081-1087. 